\title{
The Impact of Management Confidence on Capital Structure
}

\author{
Barry R Oliver ${ }^{\mathrm{a}^{*}}$ \\ ${ }^{a}$ School of Finance and Applied Statistics, Faculty of Economics and Commerce, \\ Australian National University, Canberra, 0200, Australia
}

\begin{abstract}
This paper represents one of the first studies to document the empirical relation between capital structure and management confidence. In a unique sample of US firms that have existed for over 25 years we find management confidence, as proxied by University of Michigan Consumer Sentiment Index, is highly significant in explaining firm financing decisions. When management confidence is higher firms have higher levels of debt. This result is robust to different definitions of leverage and confidence as well as different model specifications. This confirms the theoretical arguments in behavioural finance that overconfident managers will tend to issue more debt.

Market-to-book is found to be a significant determinant of capital structure as documented by previous studies. It is likely that this is due to market timing rather than growth opportunities as the sample of firms used in this study are not expected to be growth firms.

In addition, this study provides additional evidence that timing of equity issues is not persistent as documented by Baker and Wurgler (2002). The lack of significance in persistence of timing of equity issues in the sample of firms indirectly supports the results of Hovakimian (2005), that the measure is a proxy for growth opportunities.
\end{abstract}

JEL classification: G32

Keywords: Capital structure, leverage, market sentiment, confidence

* Contact details: Tel.: +61 26125 0729; fax: +61 261250729 .

Email address: Barry.Oliver@anu.edu.au. (B. Oliver)

Acknowledgements: Special thanks to Tom Smith for comments on earlier drafts. 


\section{Introduction}

Corporate capital structure remains a controversial issue in modern corporate finance. Since the seminal work by Modigliani and Miller (1958), a plethora of research has been undertaken in attempting to identify the determinants of capital structure. Traditionally, this has revolved around agency costs, asymmetric information and transaction cost issues.

Recently, behavioral finance has begun to take a more prominent position in attempting to explain aspects of finance that traditional research has failed to explain. For example, classical finance theory leaves no role for investor sentiment in stock returns. A perusal of articles forthcoming in the Journal of Finance provides ample evidence of the important impact that behavioral finance is having on mainstream research in finance.

The purpose of this paper is to add to the growing body of research in behavioral finance and to provide additional empirical support to traditional capital structure research by considering the impact of management confidence on capital structure decisions. The paper is organized as follows. Section 2 considers the major traditional determinants of capital structure and introduces the hypothesized impact that management confidence has on capital structure. Section 3 describes the method and data and section 4 documents the results. Section 5 provides conclusions.

\section{Capital structure determinants and variable definitions}

Modigliani and Miller (1958) are widely regarded as the pioneers in modeling the relevance of capital structure to firm value. Since then the debate has progressed from theoretical modeling to practical reality. It is recognized that by relaxing the assumptions of Modigliani and Miller (1958) capital structure is relevant to firm value. These assumptions generally relate to firm characteristics such as firm size, growth opportunities, collateral value of assets and profitability. The empirical evidence on the impact of these characteristics is mixed (Hovakimian, 2005). Generally, the relation firm characteristics 
have to capital structure is consistent with tradeoff theories. ${ }^{1}$ However, the tradeoff theories are not universally accepted. Shyam-Sunder and Myers (1999) report that a simple pecking order model outperforms the target adjustment model in explaining the time-series variation in capital structure.

Typically, many of the existing empirical studies rely on firm fundamental characteristics in explaining capital structures, largely ignoring the possible role that individual managers may play in capital structure choice. Interestingly, management influence on investment decisions has been researched quite extensively. The seminal work in this area is Roll (1986). Although a considerable amount of research has been done on management influence on investment decisions, very little has been done until recently on management influence on financing decisions.

Roll (1986) uses CEO overconfidence to explain why many mergers are ex-post value destroying. Roll's hubris hypothesis argues that managers are too optimistic about the performance of their acquisitions as they overestimate the benefits of the takeover. This leads to excessively high bids for targets and in turn ex-post loss making takeovers. Malmendier and Tate (2003) show that overconfident CEOs are more likely than rational CEOs to undertake value-destroying acquisitions. The issue of overconfidence and the impact it has on investment decision making is reviewed in Englmaier (2004).

From a financing and capital structure perspective, Hackbarth (2004) shows theoretically that overconfident managers choose higher debt levels and tend to time capital structure decisions. Graham and Harvey (2001) surveyed 392 CFOs and found that recent stock price performance is the third most popular reason for equity issuance decisions. ${ }^{2}$ Baker and Wurgler (2002) document empirically that managers are more likely to

\footnotetext{
${ }^{1}$ See, for example Titman and Wessels (1988), Rajan and Zingales (1995) and Hovakimian (2005).

${ }^{2}$ Interestingly, the second most important issue is the amount by which the stock is undervalued or overvalued by the market. The most important issue is earnings per share dilution.
} 
issue equity when their stock market values are higher than book and past market values. ${ }^{3}$ In other words managers time the market when making capital structure decisions. However, whether capital structure is the cumulative outcome of past attempts to time the equity market, and the persistence of market timing has been debated by Baker and Wurgler (2002), Hovakimian (2005) and Alti (2006). Irrespective, both Baker and Wurgler (2002) and Hovakimian (2005) find a significant negative relation between leverage and market-tobook. This provides support for a market timing effect- that managers' beliefs about stock prices may influence their decisions about issuing debt or equity. An alternative view is that this relation is driven by growth opportunities (Hovakimian, 2005).

In relation to confidence and stock returns, considerable research has been conducted. Neal and Wheatley (1998) examine the forecast power of three measures of individual confidence or sentiment. They find some evidence of predictability of stock returns, particularly for small firms. Brown and Cliff (2005) find strong and consistent support for the hypothesis that asset values are affected by investor sentiment. Charoenrook (2005) also finds predictability in consumer confidence or sentiment and stock returns. Therefore, if there is a relation between equity values and capital structure, and market confidence and equity values, what effect does management confidence have on capital structure? To explore this relation further we need to consider management decision making with overconfident managers.

\subsection{Overconfidence}

Psychologists have determined that overconfidence causes people to overestimate their knowledge, underestimate their risks and exaggerate their ability to control events (Nofsinger, 2003). There are numerous examples of overconfidence. For a good review see Englmaier (2004).

\footnotetext{
${ }^{3}$ This follows from Myers and Majluf (1984) and asymmetric information between management and investors.
} 
Psychologists believe that emotions and moods that are not related to the decision at hand can exert influence on that decision. Nofsinger (2003) suggests that the general level of optimism/pessimism in society affects financial decision-makers' mood and can lead to market wide phenomenon. Optimism (and overconfidence) leads corporate managers to make corporate investment, use more debt financing, and conduct more acquisitions. Hackbarth (2004) also shows theoretically that overoptimistic and/or overconfident managers choose higher debt levels and issue new debt more often. An optimistic society is more willing to take on additional debt and increase spending. However, little empirical research is available to determine if a relation exists between management confidence and capital structure.

\section{Method and Data}

\subsection{Method}

The ordinary least squares regression of leverage with robust $t$-statistics reflecting standard errors adjusted for Heteroscedasticity is: ${ }^{4}$

$$
\begin{aligned}
\operatorname{LEVERAGE}_{i, t}= & \alpha_{0}+\alpha_{1} \operatorname{CONF}_{i, t-1}+\alpha_{2} M B_{i, t-1}+\alpha_{3} \text { EFWAMB }_{i, t-1} \\
& +\alpha_{4} \operatorname{SIZE}_{i, t-1}+\alpha_{5} \operatorname{TNG}_{i, t-1}+\alpha_{6} P R F_{i, t-1}+\varepsilon_{i, t}
\end{aligned}
$$

This follows Baker and Wurgler (2002) and Hovakimian (2005) amongst others.

Leverage for firm $i$ at time $t$, is defined as:

$$
\text { LEVERAGE }_{i, t}=\frac{\text { Long term debt }_{i, t}+\text { Short term debt }_{i, t}}{\text { Total assets }_{i, t}} .
$$

Rajan and Zingales (1995) discuss the pros and cons of various leverage measures. We consider the impact of alternative proxies on the results later in the paper.

The independent variables used in equation (1) are as follows.

\footnotetext{
${ }^{4}$ Different specifications and tests of equation (1) and different definitions of the dependent and independent variables are considered later in the paper.
} 


\subsubsection{Management confidence (CONF)}

There are many measures of sentiment. For example, Neal and Wheatley (1998) consider discounts on closed-end funds, the ratio of odd-lot sales to purchases and net mutual fund redemptions to reflect individual investor confidence. Brown and Cliff (2005) use data from Investor's Intelligence, which tracks the number of market newsletters that are bullish, bearish or neutral and the bull-bear spread as measures of confidence. Generally, these measures are not available over a sufficient period for meaningful results from equation (1) to be obtained.

We proxy management confidence (CONF) as the average of the past 12 months Consumer Sentiment Index (CSI) from the University of Michigan from 1978 to 2004. This measure of confidence is based on a direct survey of public perceptions about current and expected economic conditions, and it has a sufficiently long time period for meaningful results to be obtained. The monthly CSI is based on an ongoing nationally representative survey based on approximately 500 telephone interviews with adult men and women living in households in the coterminous United States (48 States plus the District of Columbia). The sample is designed to maximize the study of change by incorporating a rotating panel sample design in an ongoing monthly survey program. For each monthly sample, an independent cross-section sample of households is drawn. The respondents chosen in this drawing are then re-interviewed six months later. A rotating panel design results, and the total sample for any one survey is normally made up of $60 \%$ new respondents, and $40 \%$ being interviewed for the second time.

The CSI is an average of scores from five survey questions that ask respondents about their current financial situations; the expected change in their financial situations over the next year; their views on expected business conditions in the next year and the next five years; and whether they think this is a good time or a bad time to make big-ticket household 
purchases. The actual survey questions and construction method of the index are presented in Appendix 1.

For a half-century, the CSI has consistently outperformed other measures in anticipating changes in the GDP six to nine months before they occur (Weiss, 2003). Qiu and Welch (2005) find it the only good measure of UBS/Gallup investor sentiment. ${ }^{5}$ Virtually all published academic research on consumer sentiment focuses on the CSI (Charoenrook, 2003). Furthermore, the US federal government has included it among its leading economic indicators since 1989 (Weiss, 2003). We consider the CSI to be a suitable proxy for US management confidence or sentiment.

\subsubsection{Market-to-book (MB)}

Baker and Wurgler (2002) document that market-to-book affects leverage. Generally, firms are more likely to issue equity when their market values are high, relative to book values and repurchase equity when their market values are low. Market-to-book is defined as:

$$
M B_{i . t}=\frac{\text { Total assets }_{i, t}-\text { book equity }_{i, t}+\text { market equity }_{i, t}}{\text { Total assets }_{i, t}}
$$

However, market-to-book is also a common measure for growth opportunities (Rajan and Zingales, 1995). Therefore, market-to-book can be regarded as a proxy for growth opportunities and market timing. However, if firms that are less likely to have growth opportunities have a significant coefficient on $M B$ then it could be concluded that market-tobook is evidence of market timing not growth opportunities. Firms less likely to have growth opportunities are older more established firms.

\footnotetext{
${ }^{5} \mathrm{UBS} /$ Gallup investor sentiment index is only available from 1996.
} 


\subsubsection{External Finance Weighted Average Market-to-Book (EFWAMB)}

External-finance-weighted-average-market-to-book has been used by Baker and Wurgler (2002) to measure the persistence of long-past market to book ratios. Baker and Wurgler (2002) contend that a negative relation on this variable occurs because firms do not subsequently adjust their leverage towards the target, the changes in leverage induced by equity market timing persist. As a result long-past market to book ratios have a negative effect on current debt ratios. It is defined as:

$$
E F W A M B_{i, t}=\sum_{s=1}^{t-1} \frac{\left(e_{s}+d_{s}\right)}{\sum_{r=1}^{t-1}\left(e_{r}+d_{r}\right)} x M B_{i, s}
$$

where $e$ and $d$ denote net equity and net debt issued, respectively. Net equity issued is defined as:

$$
e_{i, t}=\frac{\left(\text { Book equity }_{i, t}-\text { book equity }_{i, t-1}\right)-\left(\text { retained earning }_{i, t}-\text { retained earnings }_{i, t-1}\right)}{\text { Total assets }_{i, t}}
$$

Net debt issued is defined as:

$$
d_{i, t}=\frac{\text { Total assets }_{i, t}-\left[\left(\text { bookequity }_{i, t}-\text { book equity }_{i, t-1}\right)-\left(\text { retained earnings }_{i, t}-\text { retained earning }_{i, t-1}\right)\right]}{\text { Total assets }_{i, t}}
$$

Hovakimian (2005) argues that EFWAMB is a proxy for growth opportunities, as has been suggested for market-to-book, rather than a measure of market timing persistence. If $E F W A M B$ is a proxy for growth opportunities then we would expect $E F W A M B$ for older more established firms to be not significantly related to leverage. If $E F W A M B$ is significantly related to leverage for older more established firms (ie non growth firms) then it could be concluded that market timing is persistent. 


\subsubsection{Firm Size (SIZE)}

Firm size has been found to be a positive determinant of capital structure (Agrawal and Nagarajan, 1990; Baker and Wurgler, 2002; Hovakimian, 2005). Firm size may be a proxy for numerous variables such as lower transaction costs in issuing debt, greater access to debt markets and lower information asymmetries. The natural logarithm of total sales is commonly considered a proxy for the size of each firm:

$$
\operatorname{SIZE}_{i, t}=\operatorname{Ln}\left(\text { Total sales }_{i, t}\right) .
$$

\subsubsection{Tangibility of Assets (TNG)}

The collateral value of assets, or tangibility of assets, held by a firm has found to be a determinant of leverage (Rajan and Zingales, 1995). Firms with higher tangible assets are expected to have higher leverage. Tangible assets are likely to have an impact on the borrowing decisions of a firm because they are less subject to informational asymmetries and usually they have a greater value than intangible assets in case of bankruptcy. Additionally, the moral hazard risks are reduced when the firm offers tangible assets as collateral, because this constitutes a positive signal to the debt holders.

Following Hovakimian (2005) we define the collateral value of assets for each firm as:

$$
T N G_{i, t}=\frac{\text { Property plant and equipment }_{i, t}}{\text { Total } \text { assets }_{i, t}}
$$

\subsubsection{Firm Profitability $(P R F)$}

Myers (1984) pecking order theory of capital structure shows that if a firm is profitable then it is more likely that financing would be from internal sources rather than external sources. More profitable firms are expected to hold less debt, since it is easier and more cost effective to finance internally. 
The variable chosen to measure profitability for each firm follows Baker and Wurgler (2002):

$$
P R F_{i, t}=\frac{{\text { Earnings before interest, } \text { tax }_{\text {and }} \text { depreciation }}_{i, t}}{\text { Total } \text { assets }_{i, t}}
$$

\subsection{Data}

The Osiris database was searched for the largest 500 US industrial companies on total assets as of 2004. Since the Michigan Consumer Sentiment Index was readily available from 1978 this began the starting year. The Compustat files were searched for the top 500 companies that existed in 1978 and continued to exist until 2004. These companies made up the final common sample of 229 companies and 5,508 firm years. ${ }^{6}$ These companies represented the largest and longest surviving firms in the US over the past 27 years. They represent relatively lower growth firms given their long history.

Summary statistics for these firms are provided in Table 1.

\section{[TABLE 1 HERE]}

These statistics are comparable to those reported in Hovakimian (2005). However, the firms in our sample are those that have existed across the whole sample period. They are survivors, at least from 1978 through 2004.

The average value of management confidence over the sample period is approximately 90 . The maximum of 107.6 occurred in the year 2000 and the minimum of 64.4 occurred in 1980. A graph of CONF and the average annual value of $L E V E R A G E$ from 1978 to 2004 is shown in Figure 1. ${ }^{7}$

\section{[FIGURE 1 HERE]}

\footnotetext{
${ }^{6} 229$ firms for 27 years is 6,183 . There were 666 observations where data for a specific variable in equation (1) was not available on Compustat. Nine observations were deleted where LEVERAGE was in excess of $100 \%$.

${ }^{7}$ There are 229 firms in the sample, the $C O N F$ variable is set to be the same for each firm in any given year.
} 
Comparing Table 1 to Hovakimian (2005) firms in our sample have higher leverage, are larger in size, have higher tangible assets and are more profitable than the sample used by Hovakimian (2005). As we expect for our sample of well established, relatively lower growth firms firms, they have a lower average market-to-book $(1.35 \mathrm{v} 1.54)$ and a lower external finance weighted average market to book $(1.28 \mathrm{v} 1.63)$ than the firms in Hovakimian (2005).

On average the sample of our firms have approximately $30 \%$ leverage. The maximum value of leverage is $100 \%$.

Tangible assets averaged about $50 \%$ of total assets, and total assets provided an average of $14 \%$ per annum return.

A Jacques-Bera test for normality rejected the null of normality in the distribution for each variable, except SIZE. This is expected given the construction of this variable. ${ }^{8}$

Table 2 reports results of correlation between variables. As shown in Table 2 multicollinearity is unlikely to be a major concern. The variable $M B$ has a relatively high positive correlation with $P R F(0.524)$ and a relatively high negative correlation with $T N G$ (0.417). The regression equation (1) was conducted excluding $M B$ and the significance of the other coefficients remained similar to those reported. ${ }^{9}$

[TABLE 2 HERE]

\footnotetext{
${ }^{8}$ A test for normality on the 27 values of $C O N F$ for each year failed to reject the null of normality.

${ }^{9}$ A redundant variables test was conducted on $M B$. The log-likelihood ratio is 68.4 indicating $M B$ is highly significant.
} 


\section{Results}

The results of regression equation (1) are shown in Table 3 . The regression of equation (1) is highly significant with an adjusted $\mathrm{R}^{2}$ of $25 \%$. This compares with an $\mathrm{R}^{2}$ of $17.6 \%$ in Hovakimian(2005).

\section{[TABLE 3 HERE]}

The coefficient on the variable $C O N F$ is positive and significant. This indicates that when our proxy for management confidence is higher, firms have higher leverage. ${ }^{10}$ This supports the notion that optimism (and overconfidence) causes managers to overestimate the probability of success and underestimate the risk of the decision outcomes. This leads corporate managers to use more debt financing. An optimistic society is more willing to take on additional debt and increase spending.

The coefficient on market-to-book is negative indicating that when market values are relatively high leverage is low. This supports the market timing results of Baker and Wurgler (2002) and Hovakimian (2005).

Interestingly, the external finance equally weighted market to book variable $(E F W A M B)$ is not significant. Baker and Wurgler (2002) contend that the significant negative relation between $E F W A M B$ and leverage that they find is because firms do not subsequently adjust their leverage towards the target after market timing. The changes in leverage induced by equity market timing persist. As a result, long-past market-to-book ratios have a negative effect on current debt ratios. The results in Table 3 for the coefficient on $E F W A M B$ do not provide evidence of persistence in equity market timing. Hovakimian (2005) and Baker and Wurgler (2002) find a significant negative relation between EFWAMB and Leverage. However, Hovakimian (2005) contends that the negative relation is not due to persistence in market timing but due to effects of growth opportunities.

\footnotetext{
${ }^{10}$ Note that the proxy for management confidence is lagged one period in equation (1).
} 
Hovakimian (2005) and Baker and Wurgler (2002) consider both non-IPO and IPO firms. A possible reason for the insignificance in our results is that our sample is comprised of all firms that existed from 1978 to 2004 , there are no IPO firms, unless they listed in 1978, which is unlikely to be a large number. Therefore, the insignificant coefficient on EFWAMB is evidence that market timing does not persist and the significant coefficients documented by Baker and Wurgler (2002) and Hovakimian (2005) are more likely due to growth opportunities.

The three main control variables (size, tangibility of assets and profitability) all show as having highly significant coefficients. Firms that are larger are significantly positively correlated with higher leverage. This supports the hypotheses that these firms have lower transaction costs in issuing debt, greater access to debt markets and lower information asymmetries.

Firms with higher tangibility of assets have a positive correlation with leverage. This supports the hypothesis that these firms are likely to have relatively lower information asymmetries, lower bankruptcy risk and moral hazard risks.

More profitable firms are correlated with less leverage. This supports the pecking order theory of capital structure.

\subsection{Robustness tests}

The first test of robustness is to consider the impact of different specifications of LEVERAGE. The definition of leverage used in equation (1) is based on book values. An alternative specification is to base leverage on market values, particularly market value of equity. Leverage is redefined as:

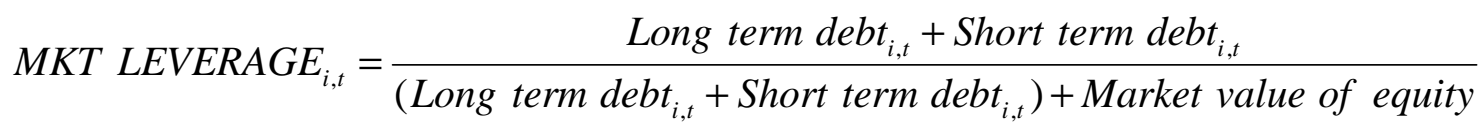

This measure of leverage is applied as the dependent variable in equation (1). The results are consistent with those previously reported. 
The variable $L E V E R A G E$ (and MKT LEVERAGE) can only take on values between zero and one. A firm with zero leverage indicates that it is all-equity financed and a firm with leverage of 1 indicates it is all-debt financed, technically bankrupt. The regression equation (1) was re-run using a Censored Normal (TOBIT) regression. The results using either definition of leverage were consistent as those previously reported.

Also the regression equation (1) was re-defined as:

$$
\begin{aligned}
\Delta L E V E R A G E_{i, t}= & \alpha_{0}+\alpha_{1} \operatorname{CONF}_{i, t-1}+\alpha_{2} M B_{i, t-1}+\alpha_{3} \text { EFWAMB }_{i, t-1} \\
& +\alpha_{4} \operatorname{SIZE}_{i, t-1}+\alpha_{5} T N G_{i, t-1}+\alpha_{6} P R F_{i, t-1}+\alpha_{7} \text { LEVERAGE }_{i, t-1}+\varepsilon_{i, t}
\end{aligned}
$$

Where $\triangle L E V E R A G E_{i, t}$ is defined as the change in LEVERAGE from $\mathrm{t}$ to $\mathrm{t}-1$. The other variables are as previously defined.

Baker and Wurgler (2002) argue that a lagged value of LEVERAGE is required in equation (2) as leverage is bounded between zero and one. When leverage is near one of these boundaries, the change in leverage can only go in one direction, regardless of the values of the other variables. Not controlling for lagged leverage may obscure the effects of the other variables. Specifically, the purpose of equation (2) is to identify the impact of the independent variables on current financing decisions. The results of this regression are shown in Table 4.

\section{[TABLE 4 HERE]}

The variable CONF remains significant as does $M B$. This suggests that confidence and market-to-book ratio is significantly related to current financing decisions. This means that the level of confidence and market-to-book have a significant effect on incremental decisions to change the current capital structure even after controlling for pre-decision leverage and other relevant factors.

The results in Table 4 on the control variables are quite different from Hovakimian (2005, Table 7). Firm size is now insignificant as is profitability. EFWAMB also remain insignificant. To ascertain if CONF is driving these results, regression equation (2) was run 
excluding CONF. The results become remarkably similar to Hovakimian (2005), except for $E F W A M B$ which remains insignificant. These results further support the conclusion that $E F W A M B$ is a proxy for growth and not persistence in market timing. This also further supports the conclusion that management confidence is a significant variable in capital structure choice.

The proxy for management confidence was re-defined as the measure of the Consumer Sentiment Index from the University of Michigan as at January of each of the years 1978 to 2004 as well as at December of the years 1978 to 2004, rather than the monthly average for the year. In both cases the coefficient on CONF in equation (1) remains highly significant.

Considering Figure 1, it is apparent that there is a general upward trend in CSI. LEVERAGE also appears to have a slight upward trend. Therefore, the positive significance of CONF may be just indicating that both leverage and confidence have increased over time. To assess the impact of time, a time variable was included in equation (1). Although the time variable is significant, the confidence variable remains positive and highly significant.

Market-to-book was redefined as:

$$
M B_{i . t}=\frac{\text { Market equity }_{i, t}}{\text { Book equity }_{i, t}}
$$

This measure of market-to-book is applied in equation (1). The results are consistent with those previously reported.

\section{Conclusion}

This paper represents one of the first studies to document an empirical relation between capital structure and confidence or sentiment. In a unique sample of US firms that have existed for over 25 years we find that management confidence as proxied by the University of Michigan Consumer Sentiment Index is pervasive and highly significant in explaining firm financing decisions. When confidence is higher firms have higher levels of debt. This 
result is robust to different regression models and different specifications, as well as different definitions of leverage and confidence. This supports the theoretical arguments in behavioural finance that overconfident managers tend to issue more debt.

Market-to-book is found to be a significant determinant of capital structure as documented by previous studies. It is likely that this is due to market timing rather than growth opportunities as the sample of firms used in this study are not expected to be growth firms.

This study also provides additional evidence that timing of equity issues is not persistent as documented by Baker and Wurgler (2002). The lack of significance in persistence of timing of equity issues in the sample of firms indirectly supports the results of Hovakimian (2005), that the measure is a proxy for growth opportunities. 


\section{References}

Agrawal, A., and Nagarajan, N.J. 'Corporate capital structure, agency costs and ownership control: The case of all-equity firms', Journal of Finance 45(4), (1990), 1325-31.

Alti, A. 'How persistent is the impact of market timing on capital structure', Journal of Finance, (2006 forthcoming).

Baker, M., and Wurgler, J., 'Market timing and capital structure', Journal of Finance 57(1), (2002), 1-32.

Brown, G. and Cliff, M. 'Investor sentiment and asset valuation', Journal of Business 78, (2005), 405-439.

Charoenrook, A. 'Does sentiment matter', Working paper-3301937, (2005), University of New Orleans.

Englmaier, F. 'A brief survey on overconfidence', Working paper-Economics Department, (2004), University of Munich.

Graham, J. and Harvey, C. 'The theory and practice of corporate finance: evidence from the field', Journal of Financial Economics 60, (2001), 187-243.

Hackbarth, D. 'Managerial optimism, overconfidence and capital structure decisions', European Finance Association Annual Meeting, (Aug, 2004), Maasticht, The Netherlands.

Hackbarth, D. 'Managerial Traits and Capital Structure Decisions', Social Science Research

Network, (September 15, 2004), http://ssrn.com/abstract=362740.

Hovakimian, A., 'Are observed capital structures determined by equity market timing', Journal of Financial and Quantitative Analysis, (2005 forthcoming).

Malmendier, U. and Tate, G. 'CEO Overconfidence and corporate investment', Journal of Finance, (2005 forthcoming).

Modigliani, F. and Miller, M.H. 'The cost of capital, corporation finance and the theory of investment', American Economic Review 53, (1958), 261-97.

Myers, S. 'The capital structure puzzle', Journal of Finance 39, (1984), 575-92.

Myers, S. and Majluf, N. 'Corporate financing and investment decisions: When firms have information that investors do not have', Journal of Financial Economics 13, (1984), 187 221.

Neal, R. and Wheatley, S. 'Do measures of investor sentiment predict returns?', Journal of Financial and Quantitative Analysis 33, (1998), 523-547.

Nofsinger, J., 'Social mood and financial economics', working paper-Department of Finance, (2003), Washington State University.

Qiu, L., and Welch, I., 'Investor Sentiment Measures', Social Science Research Network, (June 7, 2005), http://ssrn.com/abstract=589641.

Rajan, R.G. and Zingales, L. 'What do we know about capital structure? Some evidence from international data', Journal of Finance 50(5), (1995), 1421-60.

Roll, R. 'The hubris hypothesis of corporate takeovers', Journal of Business 59(2), (1986), 197-216.

Shyam-Sunder, L. and Myers, S. 'Testing static tradeoff against pecking order models of capital structure', Journal of Financial Economics 51, (1999), 219-244.

Titman, S. and Wessels, R. 'The determinants of capital structure choice', Journal of Finance 43, (1988), 1-18.

Weiss, M. 'Inside consumer confidence surveys', American Demographics, (Feb, 2003). 


\section{Table 1}

\section{Descriptive statistics of sample variables}

This table reports variable descriptive statistics of the sample variables for:

LEVERAGE $E_{i, t}=\frac{\text { Long term debt } t_{i, t}+\text { Short term debt }_{i, t}}{\text { Total assets }_{i, t}}$

$S E N T_{i, t}=$ Average of the past 12 months Consumer Sentiment Index from the University of Michigan.

$E F W A M B_{i, t}=\sum_{s=1}^{t-1} \frac{\left(e_{s}+d_{s}\right)}{\sum_{r=1}^{t-1}\left(e_{r}+d_{r}\right)} x M B_{i, s}$

where $e$ and $d$ denote net equity and net debt issued, respectively. Net equity issued is defined as:

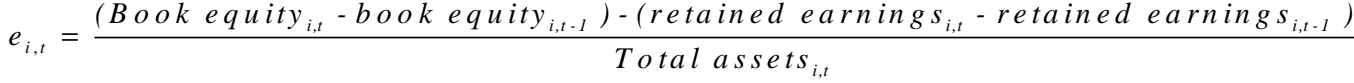

Net debt issued is defined as:

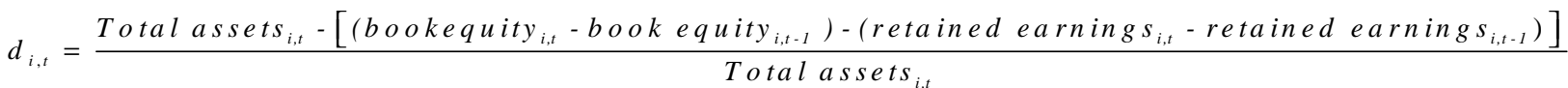

$M B_{i . t-1}=\frac{\text { Total assets }- \text { book equity }+ \text { market equity }}{\text { Total assets }}$

SIZE $E_{i, t}=L n\left(\right.$ Total sales $\left.{ }_{i, t}\right)$

$T N G_{i, t}=\frac{\text { Property plant and equipment }_{i, t}}{\text { Total } \text { assets }_{i, t}}$

$P R F_{i, t}=\frac{\text { Earnings before interest, } \text { tax and depreciation } n_{i, t}}{\text { Total assets }}$

\begin{tabular}{|l|r|r|r|r|r|r|r|}
\hline & \multicolumn{1}{|l|}{ LEVERAGE } & \multicolumn{1}{c|}{ SENT } & \multicolumn{1}{l|}{ MB } & \multicolumn{1}{l|}{ EFWAMB } & \multicolumn{1}{l|}{ SIZE } & \multicolumn{1}{l|}{ TNG } & \multicolumn{1}{l|}{ PRF } \\
\hline Mean & 0.29 & 89.29 & 1.35 & 1.28 & 7.24 & 0.47 & 0.14 \\
\hline Median & 0.31 & 92.20 & 1.14 & 1.08 & 7.24 & 0.43 & 0.13 \\
\hline Maximum & 1.64 & 107.60 & 8.98 & 101.87 & 11.93 & 0.96 & 0.69 \\
\hline Minimum & 0.00 & 64.40 & 0.60 & -118.84 & 2.00 & 0.00 & -0.40 \\
\hline Std. Dev. & 0.16 & 11.09 & 0.64 & 3.02 & 1.41 & 0.26 & 0.06 \\
\hline Observations & \multicolumn{8}{|c}{5,517} \\
\hline
\end{tabular}


Figure 1

CSI Sentiment and average Leverage (\%)1978-2004

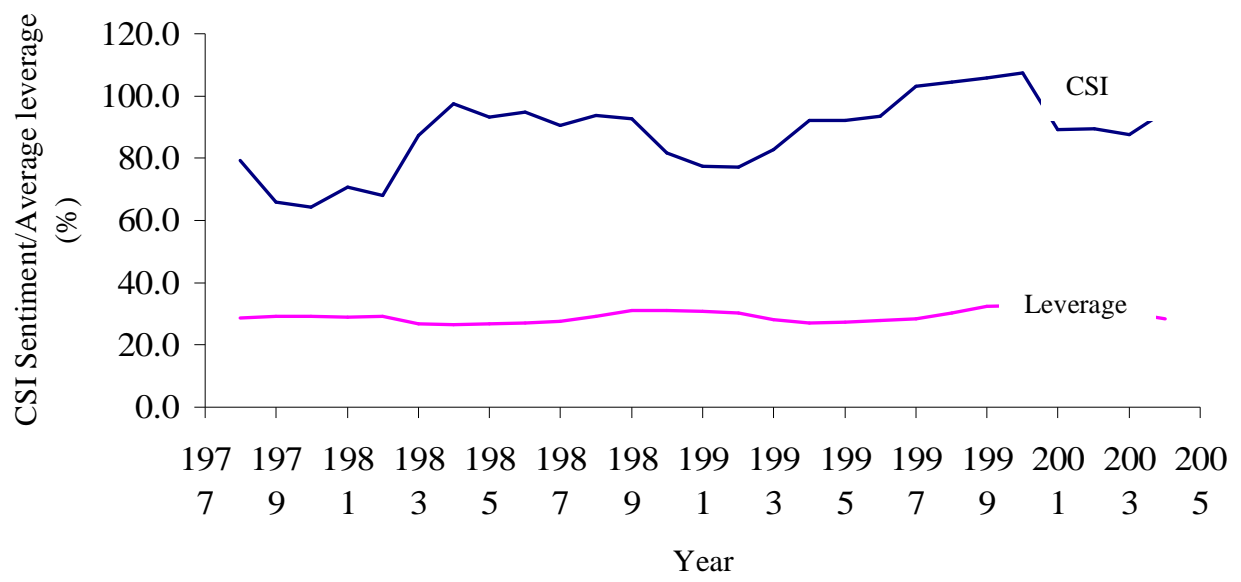


Table 2

\section{Correlation coefficients}

This table reports correlation coefficients for the regression variables:

LEVERAGE $E_{i, t}=\frac{\text { Long term debt } t_{i, t}+\text { Short term debt }_{i, t}}{\text { Total assets }_{i, t}}$

$S E N T_{i, t}=$ Average of the past 12 months Consumer Sentiment Index from the University of Michigan.

$M B_{i . t-1}=\frac{\text { Total assets }- \text { book equity }+ \text { market equity }}{\text { Total assets }}$

$$
E F W A M B_{i, t}=\sum_{s=1}^{t-1} \frac{\left(e_{s}+d_{s}\right)}{\sum_{r=1}^{t-1}\left(e_{r}+d_{r}\right)} x M B_{i, s}
$$

where $e$ and $d$ denote net equity and net debt issued, respectively. Net equity issued is defined as:

$e_{i, t}=\frac{\left(\text { Bookequity }_{i, t}-\text { bookequity }_{i, t-1}\right)-\left(\text { retained earning } s_{i, t}-{\left.\text { retained earning } s_{i, t-1}\right)}_{\text {Total assets }}\right)}{\text { Tot, }}$

Net debt issued is defined as:

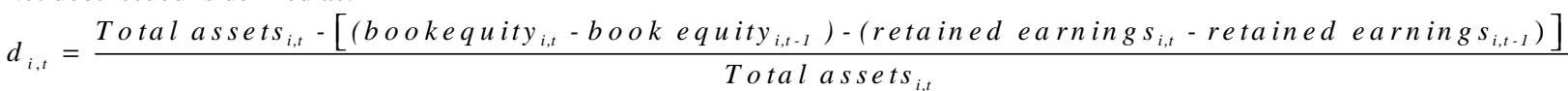

SIZE $E_{i, t}=L n\left(\right.$ Total sales $\left.s_{i, t}\right)$

$T N G_{i, t}=\frac{\text { Property plant and equipment }}{\text { Total } \text { assets }_{i, t}}$

$P R F_{i, t}=\frac{\text { Earnings before interest, } \text { tax } \text { and depreciation }}{i, t}$

\begin{tabular}{|l|r|r|r|r|r|r|}
\hline & LEVERAGE & \multicolumn{1}{l|}{ SENT } & \multicolumn{1}{l|}{ MB } & EFWAMB & \multicolumn{1}{l|}{ SIZE } & \multicolumn{1}{l|}{ TNG } \\
\hline LEVERAGE & & & & & & \\
\hline SENT & 0.001 & & & & & \\
\hline MB & -0.390 & 0.151 & & & & \\
\hline EFWAMB & -0.070 & 0.014 & 0.128 & & & \\
\hline SIZE & 0.007 & 0.221 & 0.052 & 0.004 & & \\
\hline TNG & 0.386 & -0.110 & -0.417 & -0.085 & -0.123 & \\
\hline PRF & -0.376 & 0.015 & 0.524 & 0.057 & -0.002 & -0.120 \\
\hline
\end{tabular}




\section{Table 3}

\section{Capital structure determinants}

This table reports the results of the following pooled cross-sectional time series regression (Equation 1) on the full sample of 229 US firms from 1978 until 2004:

$$
\begin{aligned}
L E V E R A G E_{i, t} & =\alpha_{0}+\alpha_{1} S E N T_{i, t-1}+\alpha_{2} M B_{i, t-1}+\alpha_{3} E F W A M B_{i, t-1} \\
& +\alpha_{4} S I Z E_{i, t-1}+\alpha_{5} T N G_{i, t-1}+\alpha_{6} P R F_{i, t-1}+\varepsilon_{i, t}
\end{aligned}
$$

where

LEVERAGE $E_{i, t}=\frac{\text { Long term debt } t_{i, t}+\text { Short term debt }_{i, t}}{\text { Total assets }_{i, t}}$

$\operatorname{SENT}_{i, t}=$ Average of the past 12 months Consumer Sentiment Index from the University of Michigan.

$M B_{i . t-1}=\frac{\text { Total assets }- \text { book equity }+ \text { market equity }}{\text { Total assets }}$

EFWAMB $B_{i, t}=\sum_{s=1}^{t-1} \frac{\left(e_{s}+d_{s}\right)}{\sum_{r=1}^{t-1}\left(e_{r}+d_{r}\right)} x M B_{i, s}$

where $e$ and $d$ denote net equity and net debt issued, respectively. Net equity issued is defined as:

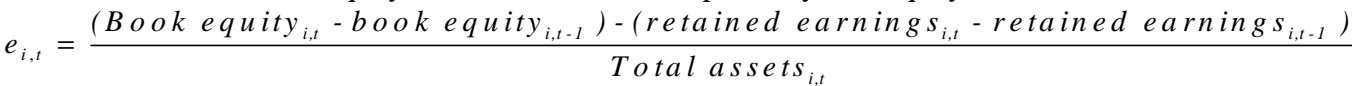

Net debt issued is defined as:

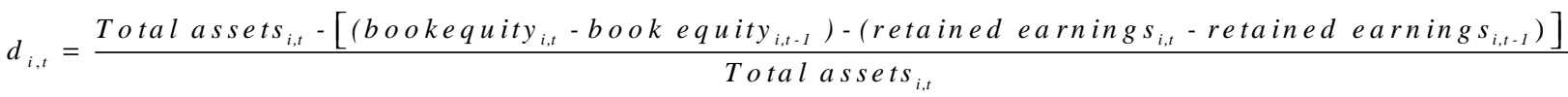

$S_{I Z E_{i, t}}=\operatorname{Ln}\left(\right.$ Total sales s $\left._{i, t}\right)$

$T N G_{i, t}=\frac{\text { Property plant and equipment }}{\text { Total }}$

$P R F_{i, t}=\frac{\text { Earnings before interest,tax and depreciation } n_{i, t}}{\text { Total assets }}$

Sample t-statistics are White (1980) adjusted for heteroskedasticity.

\begin{tabular}{|l|r|r|r|}
\hline Variable & Coefficient & t-Statistic & \multicolumn{1}{l|}{ Prob. } \\
\hline C & 0.172 & 8.894 & 0.000 \\
\hline SENT & 0.001 & 8.341 & 0.000 \\
\hline MB & -0.032 & -7.829 & 0.000 \\
\hline EFWAMB & -0.001 & -1.223 & 0.221 \\
\hline SIZE & 0.004 & 3.106 & 0.002 \\
\hline TNG & 0.193 & 24.893 & 0.000 \\
\hline PRF & -0.597 & -10.959 & 0.000 \\
\hline & & & \\
\hline Adjusted R-squared & 0.250 & & \\
\hline F-statistic & 295.796 & & \\
\hline Prob(F-statistic) & 0.000 & & \\
\hline \multicolumn{2}{|l|}{} \\
\hline
\end{tabular}




\section{Table 4}

This table reports the results of the following pooled cross-sectional time series regression (Equation 2) on the full sample of 229 US firms from 1978 until 2004:

$\triangle L E V E R A G E_{i, t}=\alpha_{0}+\alpha_{1} S E N T_{i, t-1}+\alpha_{2} M B_{i, t-1}+\alpha_{3} E F W A M B_{i, t-1}$

$$
+\alpha_{4} S I Z E_{i, t-1}+\alpha_{5} T N G_{i, t-1}+\alpha_{6} P R F_{i, t-1}+\alpha_{7} L E V E R A G E_{i, t-1}+\varepsilon_{i, t}
$$

where

$\Delta L E V E R A G E_{i, t}=\left(\frac{\text { Long term debt }_{i, t}+\text { Short term debt }_{i, t}}{\text { Total assets }_{i, t}}\right)-\left(\frac{\text { Long term debt }_{i, t-1}+\text { Short term debt }_{i, t-1}}{\text { Total assets }_{i, t-1}}\right)$

$S E N T_{i, t}=$ Average of the past 12 months Consumer Sentiment Index from the University of Michigan.

$M B_{i . t-1}=\frac{\text { Total assets }- \text { book equity }+ \text { market equity }}{\text { Total assets }}$

$E F W A M B_{i, t}=\sum_{s=1}^{t-1} \frac{\left(e_{s}+d_{s}\right)}{\sum_{r=1}^{t-1}\left(e_{r}+d_{r}\right)} x M B_{i, s}$

where $e$ and $d$ denote net equity and net debt issued, respectively. Net equity issued is defined as:

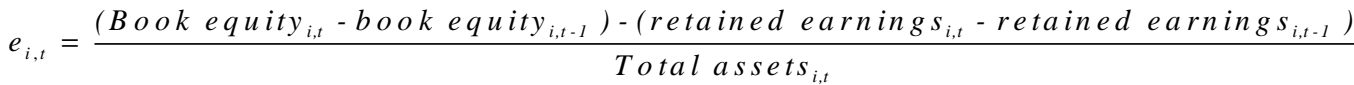

Net debt issued is defined as:

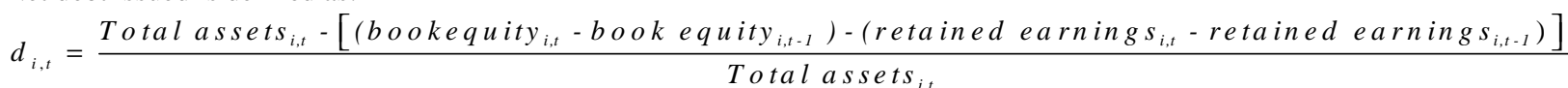

SIZE $E_{i, t}=L n\left(\right.$ Total sales $\left.s_{i, t}\right)$

$T N G_{i, t}=\frac{\text { Property plant and equipment }}{\text { Total assets }}$

$P R F_{i, t}=\frac{\text { Earnings before interest, tax and depreciation } n_{i, t}}{\text { Total assets }}$

Sample t-statistics are White (1980) adjusted for heteroskedasticity.

\begin{tabular}{|l|r|r|r|}
\hline Variable & Coefficient & \multicolumn{1}{|c|}{ t-Statistic } & \multicolumn{1}{l|}{ Prob. } \\
\hline & & & \\
\hline C & -0.041 & -4.151 & 0.000 \\
\hline SENT & 0.001 & 8.322 & 0.000 \\
\hline MB & -0.005 & -2.339 & 0.019 \\
\hline EFWAMB & 0.000 & -0.427 & 0.670 \\
\hline SIZE & 0.000 & 0.239 & 0.811 \\
\hline TNG & 0.022 & 5.048 & 0.000 \\
\hline PRF & 0.025 & 0.937 & 0.349 \\
\hline LEVERAGE & -0.117 & -7.996 & 0.000 \\
\hline & & & \\
\hline & & & \\
\hline Adjusted R-squared & 0.069 & & \\
\hline F-statistic & 57.216 & & \\
\hline Prob(F-statistic) & 0.000 & & \\
\hline
\end{tabular}




\section{Appendix 1}

Historical data for the University of Michigan Consumer Sentiment Index are available at http://www.athena.sca.isr.emich.edu and http://www.stls.frb.org/fred/. The procedure used to calculate the Index of Consumer Sentiment (ICS) as described in www.athena.sca.isr.umich.edu, Howrey (2001) and Charoenrook (2003).

To calculate the Index of Consumer Sentiment (ICS), first compute the relative scores (the percent giving favorable replies minus the percent giving unfavorable replies, plus 100) for each of the five index questions. Round each relative score to the nearest whole number. Using the formula shown below, sum the five relative scores; divide by the 1966 base period total of 6.7558; and add 2.0 (a constant to correct for sample design changes since the 1950s).

$$
I C S=\frac{\mathrm{COM}_{1}+\mathrm{COM}_{2}+\mathrm{COM}_{3}+\mathrm{COM}_{4}+\mathrm{COM}_{5}}{6.7558}+2.0
$$

COM denotes the components of the index.

$\mathrm{COM}_{1}=$ "We are interested in how people are getting along financially these days. Would you say that you (and your family living there) are better off or worse off financially than you were a year ago?"

$\mathrm{COM}_{2}=$ "Now, looking ahead—do you think that a year from now you (and your family living there) will be better off financially, or worse off, or just about the same as now?" $\mathrm{COM}_{3}=$ "Now, turning to business conditions in the country as a whole-do you think that during the next twelve months we'll have good times financially, or bad times, or what?" $\mathrm{COM}_{4}=$ "Looking ahead, which would you say is more likely-that in the country as a whole we'll have continuous good times during the next five years or so, or that we will have periods of widespread unemployment or depression, or what?"

$\mathrm{COM}_{5}=$ "About the big things people buy for their homes-such as furniture, a refrigerator, stove, television, and things like that. Generally speaking, do you think now is a good or a bad time for people to buy major household items?" 